\title{
Evaluation of radionuclides in groundwater around proposed uranium mining sites in Bagjata and Banduhurang, Jharkhand (India)
}

\author{
S. GIRI ${ }^{1}$, G. SINGH ${ }^{1}$, V.N. JHA ${ }^{2}$
}

(Manuscript received 14 August 2010, accepted 31 October 2010)

\begin{abstract}
Radionuclides find their way into the water resources at sites in the vicinity of nuclear facilities involved in mining, milling, ore separation, purification, etc. The presented study delineates the distribution of radionuclides $\{R a$ and $U(n a t)\}$ in groundwaters existing in the vicinity of two proposed uranium mine sites and evaluates their ingestion dose through the intake of drinking water. The study reveals that the U(nat) concentration in groundwater varied from $<0.5$ to $11.2 \mu \mathrm{g} . \mathrm{I}^{-1}$ in the Bagjata mining area and from $<0.5$ to $27.5 \mu \mathrm{g} . \mathrm{l}^{-1}$ in the Banduhurang mining area, while ${ }^{226} \mathrm{Ra}$ was found in the range of $<3.5$ to $206 \mathrm{mBq} . \mathrm{I}^{-1}$ and $<3.5$ to $82 \mathrm{mBq} . \mathrm{I}^{-1}$, respectively, for both areas. Seasonal variation and distribution of radionuclides in the study area did not show any definite pattern. A strong positive correlation of $U(n a t)$ in groundwater with $\mathrm{pH}$ and negative correlation of ${ }^{226} \mathrm{Ra}$ with $\mathrm{pH}$ is shown in the study. The ingestion dose to the public through intake of drinking water is estimated as $9.43 \mu \mathrm{Sv}^{-1} \mathrm{y}^{-1}$ for Bagjata and $6.28 \mu \mathrm{Sv} . \mathrm{y}^{-1}$ for Banduhurang, which is much lower than the reference limit $\left(100 \mu S v \cdot y^{-1}\right)$ given by the WHO.
\end{abstract}

Key words: Groundwater / ${ }^{226} \mathrm{Ra} /$ uranium / ingestion dose / uranium mine

RÉSUMÉ Évaluation des radionucléides dans les eaux souterraines autour de sites proposés de mines d'uranium à Bagjata et Banduhurang, Jharkhand (Inde).

Les radionucléides aboutissent dans les ressources aquatiques au voisinage des installations nucléaires impliquées dans l'exploitation minière, le broyage, la séparation du minerai, la purification, etc. L'étude présentée détaille la distribution des radionucléides ( $R$ a et $U$ naturel) dans les eaux souterraines se trouvant à proximité de 2 sites proposés de mines d'uranium et évalue la dose ingérée par l'absorption d'eau de boisson. L'étude révèle que la concentration en $U$ naturel dans les eaux souterraines variaient de 0,5 à $11,2 \mu \mathrm{g} . \mathrm{I}^{-1}$ dans la zone minière de Bagjata et de 0,5 à $27,5 \mu \mathrm{g} . \mathrm{l}^{-1}$ dans la zone minière de Banduhurang alors que le ${ }^{226} \mathrm{Ra}$ variait respectivement de 3,5 à $206 \mathrm{mBq} . \mathrm{I}^{-1}$ et de 3,5 à $82 \mathrm{mBq} . \mathrm{I}^{-1}$. La variation saisonnière et la distribution des radionucléides dans les zones étudiées n'ont pas montré de tendance définie. Une forte corrélation positive entre $U$ naturel et $\mathbf{p H}$ et une corrélation négative entre ${ }^{226} \mathrm{Ra}$ et $\mathrm{pH}$ dans les eaux souterraines sont décrites dans cette étude. La dose ingérée par le public via l'absorption d'eau de boisson est estimée à $9,43 \mu \mathrm{Sv} . \mathrm{an}^{-1}$ pour Bagjata et à $6,28 \mu \mathrm{Sv}$.an $^{-1}$ pour Banduhurang, doses qui sont bien inférieures à la limite de référence $\left(100 \mu \mathrm{Sv}^{-a^{-1}}\right)$ donnée par l'OMS.

\footnotetext{
Dept. of Environmental Science and Engineering, Indian School of Mines, Dhanbad-826004, India.
}

2 Environmental Assessment Division, Bhabha Atomic Research Centre, Mumbai-400085, India. 


\section{Introduction}

Environmental radiation originates from a number of naturally occurring and human-made sources. Radioactive materials occur naturally everywhere in the environment (e.g., uranium, thorium and ${ }^{40} \mathrm{~K}$ ). Some sources (e.g., uranium) can be concentrated during extraction by mining and other industrial activities (WHO, 2004). These can be hazardous to living tissues when they are inside an organism where radiation released can be immediately absorbed. They may also be hazardous when they are outside the organism but close enough for some radiation to be absorbed by the tissue. Therefore, it is important to know how radionuclides move through the environment and into the human body. When the pathways followed by radionuclides are known, it is possible to take remedial measures to block or avoid those pathways. Radionuclides may enter the human body by inhalation, ingestion of food and water or through the skin (Fentiman et al., 2004).

Enhanced levels of uranium and its daughter products might be present in water in areas that are rich in natural radioactivity. As groundwater moves through fractures in the bedrock that contain these deposits, radioactive minerals can leach out into the groundwater system (Firestone et al., 1996). Radionuclides find their way into the water resources at sites in the vicinity of nuclear facilities involved in mining, milling, ore separation, purification, etc. Among the radionuclides, uranium isotopes $\left({ }^{238} \mathrm{U},{ }^{234} \mathrm{U}\right.$ and $\left.{ }^{235} \mathrm{U}\right)$ have comparatively less radiotoxicity (WHO, 1978; Malcome-Lawes, 1979). However, several radionuclides in the radioactive decay chain starting from ${ }^{238} \mathrm{U}$ and ${ }^{235} \mathrm{U}$ are highly radiotoxic. The most radiotoxic among them is radium, which is a known carcinogen and exists in several isotopic forms. The predominant radium isotope in groundwater is ${ }^{226} \mathrm{Ra}$, an alpha emitter with a half-life of 1600 years (Iyengar, 1990; Marovic et al., 1996; Sidhu and Breithart, 1998). Radiation interactions with human organisms produce ionization, which triggers morphological and functional changes, consequently damaging normal behavior of cells, organs and tissues, leading to malfunction of the organ system, development of cancer and increase in mortality rate (UNSCEAR, 2000; USEPA, 1976; Wrenn et al., 1985). Correia et al. (1987) stated that the number of fatal cancers due to ${ }^{222} \mathrm{Rn}$, a daughter of ${ }^{226} \mathrm{Ra}$, ingested from drinking water may equal the fatal lung cancers due to the inhalation of indoor Rn. Considering high radiotoxicity and the associated health risks, the United States Environmental Protection Agency (USEPA) has stipulated its regulatory standards as $30 \mu \mathrm{g} . \mathrm{l}^{-1}$ for $\mathrm{U}$ (nat) and $185 \mathrm{mBq} . \mathrm{l}^{-1}$ for ${ }^{226} \mathrm{Ra}$ in drinking water. The WHO has given the standards as $15 \mu \mathrm{g} . \mathrm{l}^{-1}$ for $\mathrm{U}$ (nat) and $1 \mathrm{~Bq} . \mathrm{l}^{-1}$ for ${ }^{226} \mathrm{Ra}$ in drinking water. 
Low-grade $(0.03 \%)$ uranium deposits are found in the Singhbhum region of Jharkhand. Following this discovery, mining and processing of uranium ore has been started in several parts of eastern Singhbhum (Jaduguda, Bhatin and Narwapahar). However, with increasing requirements for nuclear energy, by 2020, new sites of mining have been proposed to be excavated for uranium. Two of the proposed new sites in Singhbhum are in Bagjata (underground) and Banduhurang (open-cast). Mining in Bagjata and Banduhurang may affect the pre-existing environmental status of the area. Thus, it is imperative to establish baseline data on the quality of water available in the study area and the dose to the public due to the radioactivity in water so that after mining the effects can be assessed. As a part of the study, the concentration of radionuclides was determined in the groundwater of the Bagjata and Banduhurang mining areas.

\section{Materials and methods}

\subsection{Description of the study area}

Located in Jharkhand, the Singhbhum Thrust Belt is an East-West-trending, 160km-long belt known for $\mathrm{Cu}$-apatite-magnetite and kyanite deposits. Studies of mineral paragenesis indicate that mineralization along the thrust belt took place over a long period, the minerals being deposited in two stages, the first to form being apatite and magnetite, closely followed by uranium mineralization, with the sulfides, including chalcopyrites, being the last to be deposited. Uranium-copper mineralization coexists in the area; however, depending upon the viability, $\mathrm{Cu}$ or $\mathrm{U}$ is mined and processed. The Bagjata mining area is situated in the BhalkiKanyaluka deposit, while the Banduhurang is in the Keoradungri deposit (Bhola et al., 1964).

The Bagjata mining area is situated at a latitude of $22^{\circ} 26^{\prime} 07^{\prime \prime} \mathrm{N}$ to $22^{\circ} 28^{\prime} 34^{\prime \prime} \mathrm{N}$ and longitude of $86^{\circ} 25^{\prime} 16^{\prime \prime} \mathrm{E}$ to $86^{\circ} 31^{\prime} 29^{\prime \prime} \mathrm{E}$ in the Dalbhum subdivision of Singhbhum district in Jharkhand State. It is an underground uranium mine. The Banduhurang mining area is situated $5 \mathrm{~km}$ South of Tatanagar railway station at a longitude of $86^{\circ} 09^{\prime} 45^{\prime \prime} \mathrm{E}$ to $86^{\circ} 11^{\prime} 30^{\prime \prime} \mathrm{E}$ and a latitude of $22^{\circ} 43$ ' $45^{\prime \prime} \mathrm{N}$ to $22^{\circ} 43^{\prime} 15^{\prime \prime} \mathrm{N}$. The proposed mining site is an open-cast uranium deposit. Near the site there are underground uranium deposits in Turamdih and Mohuldih. Both the sites are well connected with the railway stations Ghatsila and Tatanagar. There are several small villages surrounding the mining sites. Groundwater is the main source of drinking water in the villages of the area. The location of the study area is shown in Figure 1. 


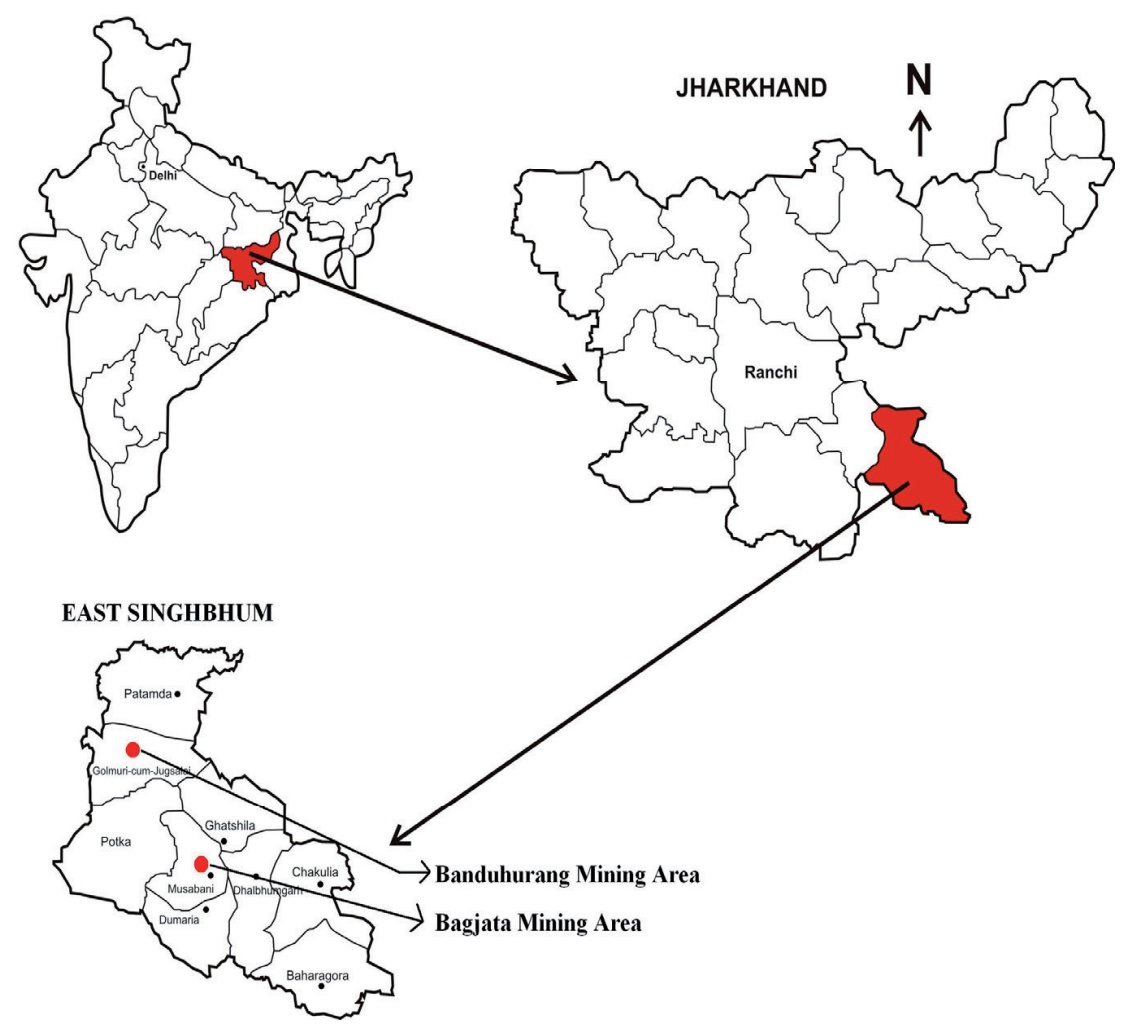

Figure 1 - Location map of the study areas.

Carte localisant les zones étudiées.

\subsection{Sample collection and preservation}

Grab samples of groundwater were collected in pre-conditioned plastic cans from 10 locations surrounding the mine sites. The data is of composite samples of triplicate samples collected from each location. The samples were collected approximately at an interval of one week in a particular month. Samples were filtered immediately after collection and preserved by acidification with conc. $\mathrm{HNO}_{3}$. After the collection of triplicate samples, they were composited and further analysis was done. 
Samples were collected during the months of June 2006, September 2006, January 2007 and May 2007. May and June were treated separately because May represents the peak summer season where most of the surface water sources dry out. June represents the onset of the monsoon and the initial precipitation may lead to the change in profile found during the summer. September symbolizes the peak monsoon, while January represents the winter season.

\subsection{Analytical methods}

Water samples (2 1) were evaporated to about $100 \mathrm{ml}$, loaded in a radon bubbler and the in-built radon was removed by evacuation. Samples were then retained in the emanometric set for 15 days for the fresh buildup of radon. Freshly built-up radon was transferred into a scintillation cell, left for 200 minutes and alpha emissions were counted in an alpha counter (after radon and progeny equilibrium was established). Finally, using the net counts, buildup period, counting duration, sampling parameters, and \% of equilibrium reached, ${ }^{226} \mathrm{Ra}$ activity were evaluated (Raghavayya et al., 1980).

For $\mathrm{U}\left(\right.$ nat) analysis, samples were evaporated with conc. $\mathrm{H}_{2} \mathrm{SO}_{4}$, refluxed in $0.25 \mathrm{~N} \mathrm{H}_{2} \mathrm{SO}_{4}$ and extracted using 2\% Alamine in Benzene (Burcik and Mikulaj 1991; Rout et al., 1994; Mackenzie, 1997). From the organic layer $0.1 \mathrm{ml}$ was transferred to a platinum planchet, fused and $U($ nat) was evaluated by the fluorometric method (Kolthoff and Elving, 1962).

\subsection{Quality control}

As a part of the quality control, spike recovery for matrix elimination was also carried out for the samples. The recovery of $U$ (nat) and ${ }^{226} \mathrm{Ra}$ was found to be $92 \%$ and $93 \%$, respectively. The results are provided in Table I. Four Certified Reference Materials supplied from BAS, U.K., were analyzed for their uranium content. The results are presented in Table II.

\section{TABLE I}

Recovery analysis of radionuclides.

Taux de récupération des radionucléides.

\begin{tabular}{cccccc}
\hline S. No & Radionuclide & $\begin{array}{c}\text { Activity of water/ml } \\
\text { of Aliquot (Bq) }\end{array}$ & $\begin{array}{c}\text { Predicted } \\
\text { Activity }\end{array}$ & Actual Activity & \% Recovery \\
\hline 1 & $\mathrm{U}(\mathrm{nat})$ & 0.024 & 0.0108 & 0.0099 & 92 \\
2 & ${ }^{226} \mathrm{Ra}$ & 0.0006 & 0.0064 & 0.00594 & 93 \\
\hline
\end{tabular}




\section{TABLE II}

Analysis of Certified Reference Material for uranium U(nat): $\mu \mathrm{g} . \mathrm{g}^{-1}$. Concentration en $\mu \mathrm{g} . \mathrm{g}^{-1}$ de l'uranium naturel dans les matériaux de référence certifiés.

\begin{tabular}{lccc}
\hline Certified Reference Material & 1 BARC Mumbai & ${ }^{\mathbf{2}}$ HPU Jadugoda & $\begin{array}{c}\text { BAS Certified } \\
\text { Concentration }\end{array}$ \\
\hline TILL-1(Soil) & 1.95 & 1.89 & 2.2 \\
TILL-3(Soil) & 1.87 & 1.80 & 2.1 \\
STSD-1 (Stream Sediment) & 7.95 & 8.16 & 8.0 \\
LKSD-1(Lake Sediment) & 9.20 & 9.30 & 9.7 \\
\hline
\end{tabular}

${ }^{1}$ Bhabha Atomic Research Centre. ${ }^{2}$ Health Physics Unit.

\section{TABLE III}

Concentration range of radionuclides and $\mathrm{pH}$ in the groundwater of the Bagjata mining area (the data range corresponds to the seasonal variation from June 2006 to May 2007).

Domaines des concentrations des radionucléides et de pH dans les eaux souterraines de la zone minière de Bagjata (l'éventail des données correspond à la variation saisonnière de juin 2006 à mai 2007).

\begin{tabular}{|c|c|c|c|c|}
\hline \multirow[t]{2}{*}{ S. No } & \multirow[t]{2}{*}{ Location } & \multicolumn{3}{|c|}{ Range } \\
\hline & & $\mathrm{U}\left(\right.$ nat) in $\mu \mathrm{g} . \mathrm{I}^{-1}$ & ${ }^{226} \mathrm{Ra}$ in $\mathrm{mBq} \cdot \mathrm{l}^{-1}$ & pH \\
\hline 1 & Bagjata & $<0.5-7.8$ & $7.5-206$ & $6.4-7.0$ \\
\hline 2 & Manajhari & $<0.5-3.8$ & $<3.5-25$ & $6.6-7.1$ \\
\hline 3 & Balidungri & $<0.5-3.5$ & $<3.5-44$ & $6.5-7.1$ \\
\hline 4 & Bakra & $1.4-3.7$ & $<3.5-7.2$ & $6.9-7.2$ \\
\hline 5 & Nimdih & $<0.5-5.1$ & $7.9-20.1$ & $6.7-6.9$ \\
\hline 6 & Gohala & $7.4-11.2$ & $<3.5-7.0$ & $7.3-7.5$ \\
\hline 7 & Phuljhari & $<0.5-5.0$ & $<3.5$ & $7.0-7.3$ \\
\hline 8 & Bhaduya & $1.2-10.1$ & $5.2-12.6$ & $6.9-7.2$ \\
\hline 9 & Mosabani & $1.5-3.4$ & $<3.5-6.5$ & $7.0-7.2$ \\
\hline 10 & Katsakra & $3.4-4.9$ & $<3.5$ & $7.2-7.3$ \\
\hline
\end{tabular}

\section{Results and discussion}

\subsection{Concentration range of radionuclides in the study area}

The concentration range of the radionuclides in the groundwater of the Bagjata mining area is given in Table III. It can be seen from the table that the overall concentration range of uranium, considering all the seasons, varied from $<0.5 \mu \mathrm{g} . \mathrm{l}^{-1}$ to $11.2 \mu \mathrm{g} . \mathrm{l}^{-1}$, whereas ${ }^{226} \mathrm{Ra}$ was found in the range of $<3.5$ to $206 \mathrm{mBq} \cdot \mathrm{l}^{-1}$. The detection limit for U(nat) was $0.5 \mu \mathrm{g} .1^{-1}$, while for ${ }^{226} \mathrm{Ra}$ it was $3.5 \mathrm{mBq} \cdot \mathrm{l}^{-1}$. The highest concentration ranges of uranium $\left(7.14-11.2 \mu \mathrm{g} . \mathrm{l}^{-1}\right)$ and 
radium (7.5-206 mBq. $\mathrm{l}^{-1}$ ) were detected in Gohala and Bagjata villages, respectively. The higher concentration of radium detected in the Bagjata village may be attributed to its proximity to the mine site. Many authors (Iyengar, 1990; Paschoa et al., 1979; Benes, 1990) have also reported high values of radionuclide concentration close to uranium mining and milling sites. Gohala village is between the Sankhnalla river and Subernarekha river, thus it may be affected by the aquifer properties of both the rivers. Groundwater and surface water are not isolated components of the hydrologic system, but instead interact in a variety of physiographic and climatic landscapes. Thus, development or contamination of one commonly affects the other (Sophocleous, 2002; Brunke and Gonser, 1997). Organic and toxic contamination in surface water can be transferred to the groundwater (Schwarzenbach et al., 1983; Santschi et al., 1987; Whittemore et al., 2000). The Subernarekha flows close to the Cu-processing industries and is affected by the $\mathrm{Cu}$-treated effluents rich in radioactivity. Thus, high radioactivity can be expected in the location.

Comparison of the concentration range of $\mathrm{U}(\mathrm{nat})$ and ${ }^{226} \mathrm{Ra}$ in groundwater with the USEPA standards shows that these radionuclide concentration ranges are within the prescribed limits, except in the case of the Ra concentration in Bagjata village. However, the radionuclides are within the standards given by the WHO. The statistical analysis of the data indicated geometric mean concentrations of $\mathrm{U}(\mathrm{nat})$ and ${ }^{226} \mathrm{Ra}$ to be $3.22 \mu \mathrm{g} . \mathrm{l}^{-1}$ and $12.44 \mathrm{mBq} . \mathrm{l}^{-1}$, with geometric standard deviations of $2.0 \mu \mathrm{g} .1^{-1}$ and $2.54 \mathrm{mBq} . \mathrm{l}^{-1}$, respectively.

The concentration range of the radionuclides found in the groundwater of the Banduhurang mining area is given in Table IV. It can be seen from the table that the overall concentration range of uranium, considering all the seasons, was found to be $<0.5 \mu \mathrm{g} .1^{-1}$ to $27.5 \mu \mathrm{g} .1^{-1}$, whereas ${ }^{226} \mathrm{Ra}$ was found to be in the range of $<3.5$ to $82 \mathrm{mBq} . \mathrm{l}^{-1}$. The highest concentration range of $\mathrm{U}(\mathrm{nat})\left(<0.5-27.5 \mu \mathrm{g} . \mathrm{l}^{-1}\right)$ and ${ }^{226} \mathrm{Ra}$ (7.3-82) was detected in Nandup and Babudih villages, respectively. Babudih is in close proximity to the mine site, which may explain its high concentration of radionuclides. Comparison of the concentration range of U(nat) and ${ }^{226} \mathrm{Ra}$ in groundwater with the USEPA standards shows that these radionuclides lie within the limits. However, the concentration of uranium in Nandup village exceeds the WHO standards. The statistical analysis of the data indicated geometric mean concentrations of $U$ (nat) and ${ }^{226} \mathrm{Ra}$ to be $2.15 \mu \mathrm{g} . \mathrm{l}^{-1}$ and $9.1 \mathrm{mBq} . \mathrm{1}^{-1}$, with geometric standard deviation of 2.0 and 3.3 , respectively. It can be seen that the concentrations of uranium and radium in the open-cast mine, i.e. the Banduhurang mining area, are comparatively lower than the underground mine, i.e. the Bagjata mining area. This may be attributed to the fact that surface mineralization of the open-cast mining area contributes less to the radionuclide 
TABLE IV

Concentration range of radionuclides and $\mathrm{pH}$ in the groundwater of the Banduhurang mining area (the data range corresponds to the seasonal variation from June 2006 to May 2007).

Domaines des concentrations des radionucléides et de pH dans les eaux souterraines de la zone minière de Banduhurang (l'éventail des données correspond à la variation saisonnière de juin 2006 à mai 2007).

\begin{tabular}{|c|c|c|c|c|}
\hline \multirow[t]{2}{*}{ No } & \multirow[t]{2}{*}{ Location } & \multicolumn{3}{|c|}{ Range } \\
\hline & & $\mathrm{U}(\mathrm{nat})$ in $\mu \mathrm{g} . \mathrm{I}^{-1}$ & ${ }^{226} \mathrm{Ra}$ in $\mathrm{mBq} \cdot \mathrm{I}^{-1}$ & pH \\
\hline 1 & Keoradungri & $<0.5-1.2$ & $4.3-8.6$ & $6.8-7.0$ \\
\hline 2 & Babudih & $<0.5-7.7$ & $7.3-82$ & $6.2-7.0$ \\
\hline 3 & Nandup & $<0.5-27.5$ & $<3.5-5.1$ & $7.9-8.5$ \\
\hline 4 & Matku & $<0.5-0.6$ & $6.4-14.2$ & $6.5-6.8$ \\
\hline 5 & Kudada & $<0.5-0.8$ & $<3.5-5.1$ & $6.8-7.2$ \\
\hline 6 & Turamdih & $<0.5-2.4$ & $<3.5-9$ & $6.8-7.2$ \\
\hline 7 & Turamdih (near proposed Tailing pond) & $<0.5-0.9$ & $<3.5-11.7$ & $6.8-7.3$ \\
\hline 8 & Talsa & $<0.5-4.3$ & $2.7-17.8$ & $6.6-7.0$ \\
\hline 9 & Chota Talsa & $<0.5-3$ & $4.1-8.3$ & $6.9-7.2$ \\
\hline 10 & Sundernagar & $<0.5-1.3$ & $8.5-12.8$ & $6.7-6.9$ \\
\hline
\end{tabular}

concentration of groundwater than the deep underground mining area, where the mineralization is near the aquifers.

In both the Bagjata and Banduhurang mining areas, apart from distance from the mine sites, other factors also appreciably result in variation in the radionuclide concentration in the groundwater of the area. The uranium mineralization in the Singhbhum Thrust Belt is sporadic and the depth of ore bodies also varies (Bhola et al., 1964). Thus, high concentration of radionuclides in the locations far from the site can also be anticipated, which is depicted in this study, in the case of Nandup village. Another important factor determining the variation in the radionuclide concentration in the groundwater is the $\mathrm{pH}$ of the water samples. The range of $\mathrm{pH}$ is given in Tables III and IV along with the range of radionuclides for the Bagjata and Banduhurang mining areas, respectively. A low $\mathrm{pH}$ value is the most important water parameter linked to high radium concentration. This is probably related to limited adsorption of radium on ferric oxides and hydroxides in soil at low pH range (Almeida et al., 2004; Lauria et al., 2004). However, an increase in the $\mathrm{pH}$ results in an increased concentration of uranium (Butler and Kahn, 1995). The present study is also in good agreement with the above facts. The correlation between the $\mathrm{pH}$ and the concentration of the radionuclides (Figs. 2 and 3 ) suggests a strong positive correlation between $\mathrm{pH}$ and $\mathrm{U}(\mathrm{nat})(R=0.712)$, and 


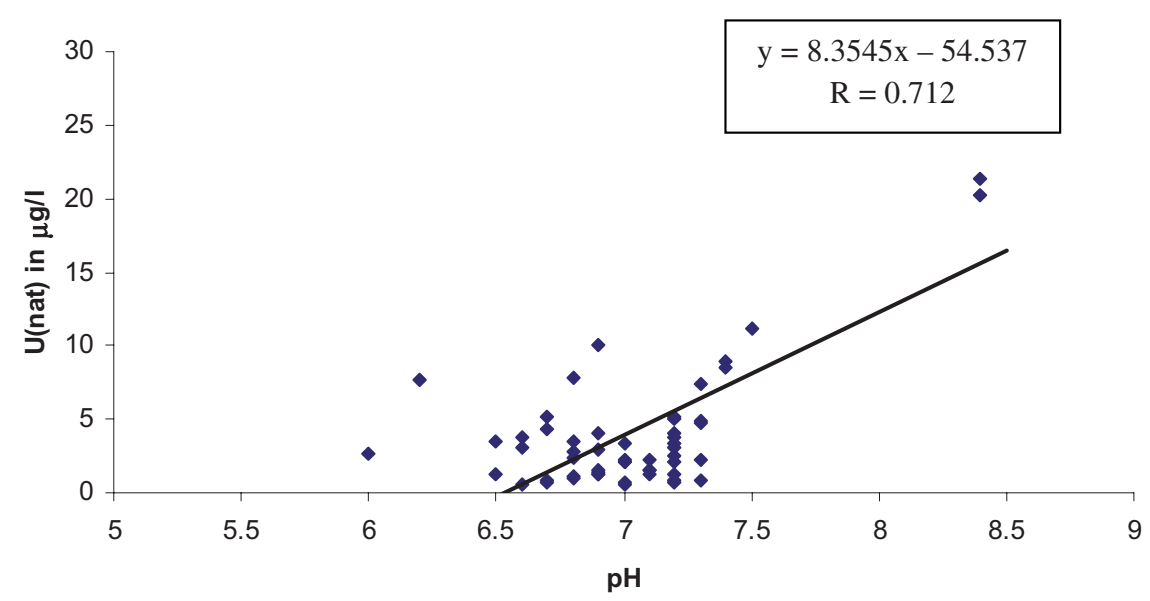

Figure 2 - Regression analysis between $p H$ and $U(n a t)$ in groundwater $(n=56)$.

Analyse de régression entre pH et $U$ naturel dans les eaux souterraines $(n=56)$.

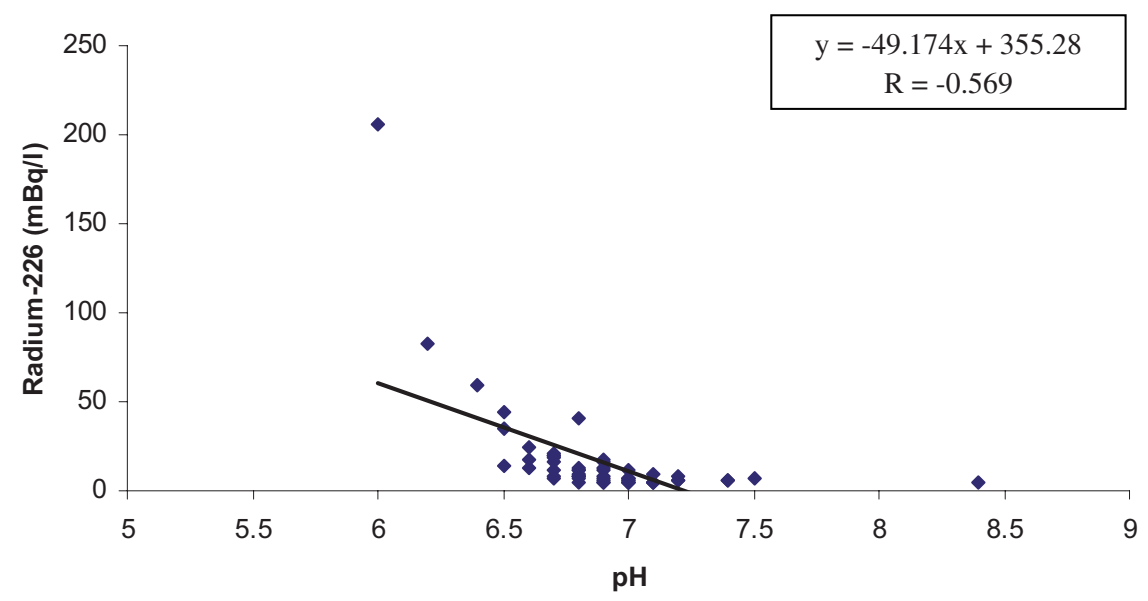

Figure 3 - Regression analysis between $p H$ and ${ }^{226}$ Ra in groundwater $(n=57)$.

Analyse de régression entre pH et ${ }^{226}$ Ra dans les eaux souterraines $(n=57)$.

a negative correlation between $\mathrm{pH}$ and ${ }^{226} \mathrm{Ra}(R=-0.569)$. This implicates a weak correlation between uranium and radium. The Pearson statistical test also confirms the same (Tab. V). The high concentration of radium in acidic water has also been reported in other studies (DePaul and Szabo, 2007). However, the concentration of uranium has a positive correlation with $\mathrm{pH}$, as increase in the $\mathrm{pH}$ resulted in an increased concentration of the uranium (Butler and Kahn, 1995; Hsi and 


\section{TABLE V}

Pearson Correlation Matrix for $\mathrm{U}, \mathrm{Ra}$ and $\mathrm{pH}$ in both the study areas. Matrice de corrélation de Pearson pour $\mathrm{U}$, Ra et $\mathrm{pH}$ dans les 2 zones étudiées.

\begin{tabular}{|c|c|c|c|c|}
\hline & & $\mathbf{U}$ & $\mathbf{R a}$ & pH \\
\hline \multirow[t]{2}{*}{$\mathbf{U}$} & Pearson correlation & 1.000 & 0.007 & $0.712 *$ \\
\hline & $\mathrm{N}$ & 56 & 40 & 56 \\
\hline \multirow[t]{2}{*}{$\mathbf{R a}$} & Pearson correlation & & 1.000 & $-0.569 *$ \\
\hline & $\mathrm{N}$ & & 57 & 57 \\
\hline \multirow[t]{2}{*}{ pH } & Pearson correlation & & & 1.000 \\
\hline & $\mathrm{N}$ & & & 80 \\
\hline
\end{tabular}

* Correlation is significant at the 0.01 level (2-tailed).

Langmuir, 1985). Approximately neutral $\mathrm{pH}$ and presence of minerals such as $\mathrm{Fe}$ oxides increase adsorption of U4+, and thus decrease its mobility. In contrast, more alkaline conditions and increased bicarbonate $\left(\Sigma \mathrm{CO}_{3}\right)$ concentration lead to greater desorption and mobility, especially of U6+ (Wanty et al., 1991).

${ }^{226} \mathrm{Ra}$ has different geochemical properties (sorption, solubility and complexation) than its parent ${ }^{238} \mathrm{U}$, and their co-occurrence is not common. Thus, weak correlations between uranium and radium have also been reported by Szabo and Zapecza (1991). Each radioactive decay product has its own unique chemical characteristics, solubility, mobility and half-life, that can be very different from those of the parent. For this reason, parent and daughter radionuclides in groundwater are not usually found together in similar amounts (Gilkeson et al., 1983).

\subsection{Seasonal variation in the concentration levels of the radionuclides}

Seasonal variations in the concentration levels of the radionuclides found in groundwater of the Bagjata mining area are shown in Figures 4 and 5 and in the Banduhurang mining area in Figures 6 and 7. It can be seen from the figures that there is wide variation in concentration of radionuclides, and hence no definite trend of seasonal variation could be established. Overall analysis of the data indicates that concentrations of these radionuclides were higher in summer (MayJune) as compared with the other seasons. The geometric mean concentration of $\mathrm{U}\left(\right.$ nat) and ${ }^{226} \mathrm{Ra}$ in the Bagjata mining area was found to be maximum, i.e., $4.39 \mu \mathrm{g} . \mathrm{l}^{-1}$ and $22.22 \mathrm{mBq} . \mathrm{l}^{-1}$ in the months of May and June, respectively; this supports the above observations.

In the Banduhurang mining area, the concentration of U(nat) in June, 2006 varied from $<0.5$ to $21.4 \mu \mathrm{g} . \mathrm{l}^{-1}$, whereas it was found to be comparatively less 


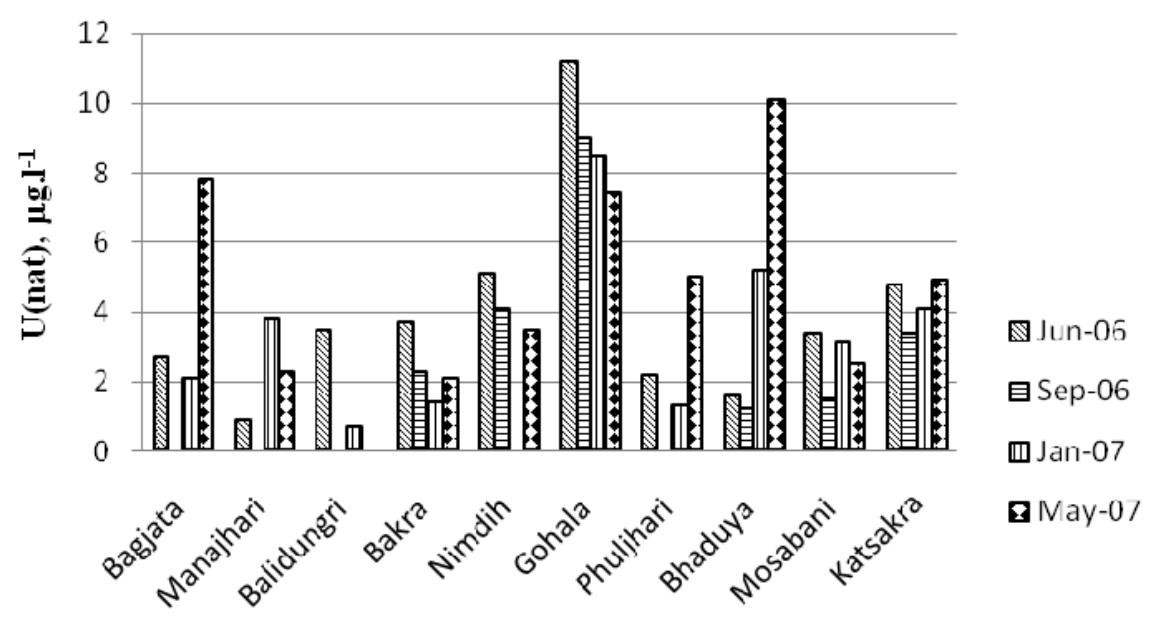

Locations

Figure 4 - Seasonal variations in U(nat) concentration in the Bagjata mining area.

Variations saisonnières de la concentration en U naturel dans la zone minière de Bagjata.

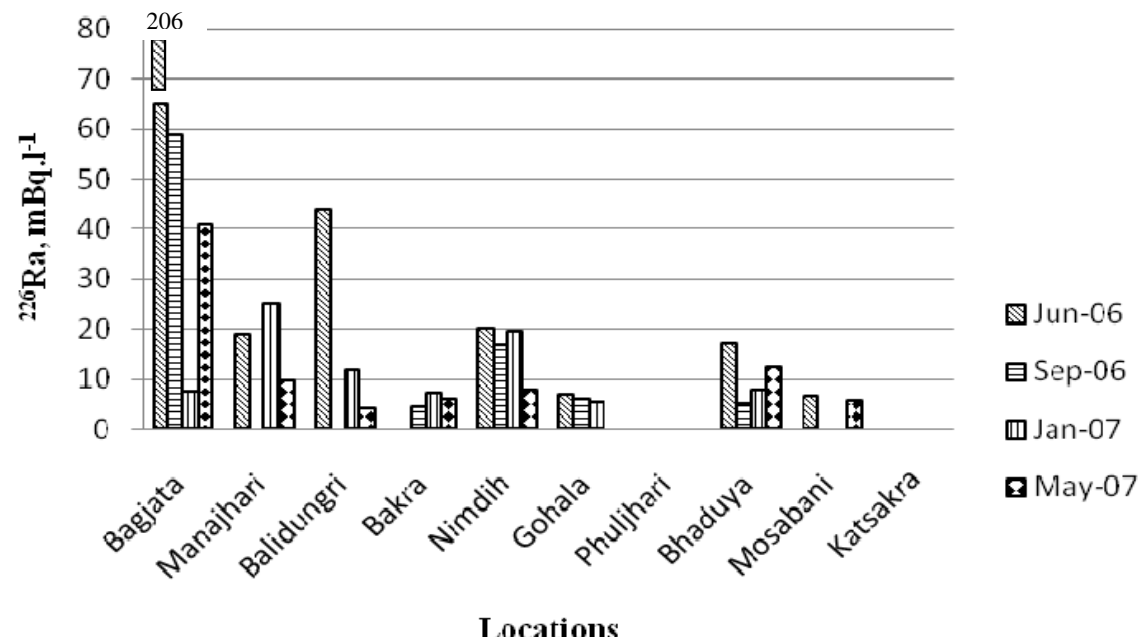

Figure 5 - Seasonal variations in ${ }^{226}$ Ra concentration in the Bagjata mining area.

Variations saisonnières de la concentration en ${ }^{226}$ Ra dans la zone minière de Bagjata. 


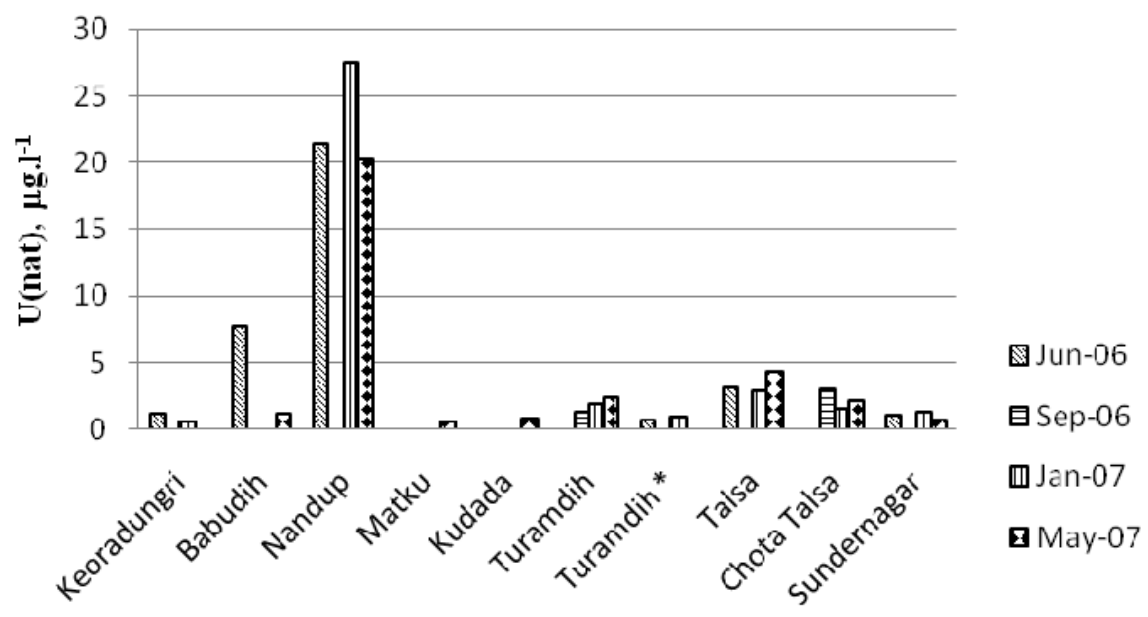

Locations

Figure 6 - Seasonal variations in U(nat) concentration in the Banduhurang mining area. *Turamdih: near proposed tailing pond.

Variations saisonnières de la concentration en U naturel dans la zone minière de Banduhurang.

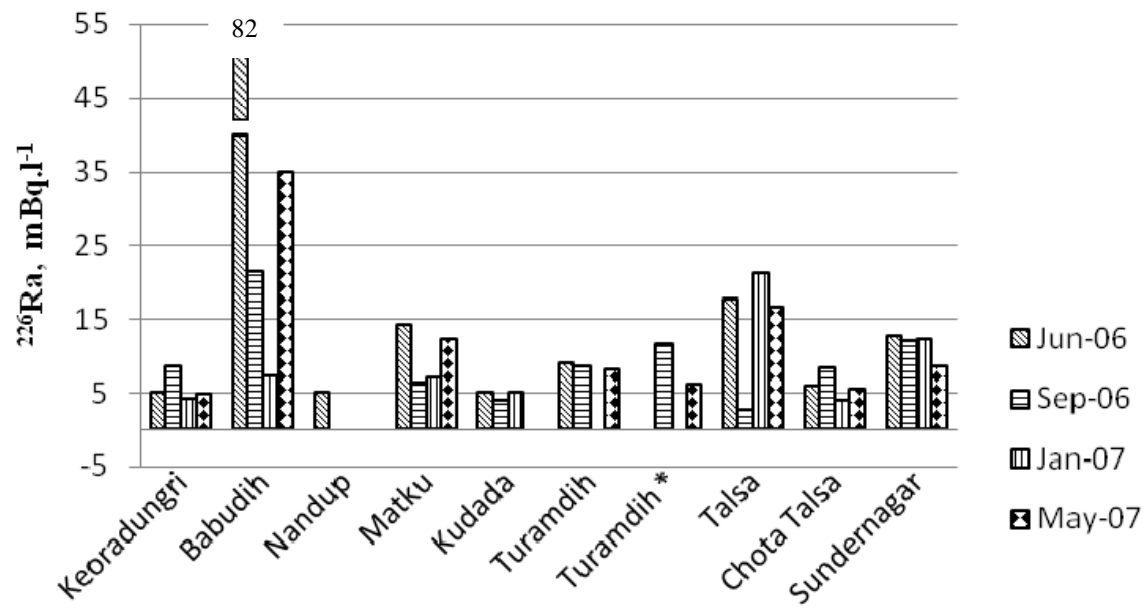

\section{Locations}

Figure 7 - Seasonal variations in ${ }^{226}$ Ra concentration in the Banduhurang mining area. *Turamdih: near proposed tailing pond.

Variations saisonnières de la concentration en ${ }^{226}$ Ra dans la zone minière de Banduhurang. 
( $<0.5$ to $3.0 \mu \mathrm{g} .1^{-1}$ ) during monsoon (September, 2006). In the case of ${ }^{226} \mathrm{Ra}$, the concentration range $\left(<3.5\right.$ to $\left.82 \mathrm{mBq} \cdot \mathrm{l}^{-1}\right)$ was found to be higher in June, 2006 while the minimum concentration range $\left(<3.5\right.$ to $\left.21.5 \mathrm{mBq} \cdot \mathrm{l}^{-1}\right)$ was found in September, 2006. Overall analysis of the data dictates that the concentrations of these radionuclides in summer were found to be comparatively higher as compared with other seasons. The maximum geometric mean concentration of $U$ (nat) and ${ }^{226} \mathrm{Ra}$, i.e. $2.75 \mu \mathrm{g} . \mathrm{l}^{-1}$ and $10.69 \mathrm{mBq} . \mathrm{l}^{-1}$, respectively, found for June supports the above observation.

Overall, the highest concentration of radionuclides was seen in the summer, i.e. the months of June and May. However, the concentration was higher for June than May. The lowest concentration was in general found in September, which represents the peak monsoon. The great variation observed for the radionuclide concentration in the water samples can possibly be explained due to the concentration factor. During the dry season the water level is much lower than the level observed in the rainy period, thus the concentration is higher in the dry period (Silva et al., 2008). Higher concentrations of radionuclides during summer have also been reported by other researchers such as Goode and Wilder (2006). The variation between the months of June and May can be explained as May represents the peak summer season where most of the surface water sources dry out. June represents the onset of the monsoon just after the summer and the initial precipitation may lead to the change in the concentration profile found during the summer. The high concentration during the summer may further be increased due to initial rainfall because of leaching of the bedrock, soil and residues of the mineralized hills. Augmentation of radionuclides due to leaching has been reported by other authors (Gascoyne, 1989; Pulhani et al., 2007). Further precipitation during the peak monsoon will dilute the source and a significant decrease is anticipated during September. Lower concentration of radionuclides in the rainy season, which could be due to dilution, has also been reported in other studies (Lydie and Nemba, 2008).

Radionuclides are ubiquitous and present in almost all the sections of the environment with wide variation. The levels of uranium in drinking water show wide variation among various regions. Tables VI and VII give the worldwide reported concentration range of uranium and radium in groundwater by various researchers. It can be seen from the tables that the concentrations of uranium and radium reported in the present investigation lie within the USEPA standards and are in good concurrence with the concentration range reported by other researchers as given in Tables VI and VII. 


\section{TABLE VI}

Worldwide reported concentration range of uranium in water.

Domaine des concentrations d'uranium dans l'eau enregistrées dans le monde.

\begin{tabular}{llll}
\hline S. No. & Location & U(nat), $\mu$ g/l & Reference \\
\hline 1 & Japan & $1.07-344$ & Shiraishi et al. (1992) \\
\hline 2 & Jordan & $0.04-1400$ & Smith et al. (2000) \\
\hline 3 & Kuwait & $0.02-2.48$ & Bou-Rabee (1995) \\
\hline 4 & United States & $0.01-652$ & Cothern and Lappenbusch (1983) \\
\hline 5 & South Greenland & $0.5-1.0$ & Brown et al. (1983) \\
\hline 6 & Turkey & $0.24-17.65$ & Kumru (1995) \\
\hline 7 & Aligarh, India & $0.67-471.3$ & Bansal et al. (1988) \\
\hline 8 & Amritsar, India & $2.0-98.3$ & Rani and Singh (2006) \\
\hline 9 & Shimla, India & $0.33-3.24$ & Rani and Singh, (2006) \\
\hline 10 & Karnataka, India & $0.15-47$ & Mahesh et al. (2002) \\
\hline 11 & Jadugoda, India & $2-6$ & Tripathi et al. (2007) \\
\hline 12 & Bagjata, India & $<0.5-11.2$ & Present study \\
\hline & Banduhurang, India & $<0.5-27.5$ & Present study \\
\hline
\end{tabular}

\section{TABLE VII}

Worldwide reported concentration range of radium in water. Domaine des concentrations du radium dans l'eau enregistrées dans le monde.

\begin{tabular}{llll}
\hline S. No. & Location & ${ }^{\mathbf{2 2 6}} \mathbf{R a}, \mathbf{~ m B q} / \mathbf{l}$ & Reference \\
\hline 1 & China & $1.11-939.8$ & Weihai et al. (2001) \\
2 & Finland & 109.9 (Mean) & Salonen (1988) \\
3 & Denmark & $551.3($ Mean) & Ulback and Klinder (1984) \\
\hline 4 & Tunisia & 34.04 & Labidi et al. (2002) \\
\hline 5 & Egypt & $79.2($ Mean) & Nour Khalifa (2004) \\
\hline 6 & Germany & $2.96-22.2$ & Hoffmann et al. (1993) \\
7 & New Jersey, U.S & $<18.5-643.8$ & US Geological Survey (2004) \\
8 & Finland & $10-1000$ & Vesterbacka et al. (2006) \\
\hline 9 & Rio de Janeiro & $2-492$ & Almeida et al. (2004) \\
10 & Bagjata, India & $<3.5-206$ & Present study \\
11 & Banduhurang, India & $<3.5-82$ & Present study \\
\hline
\end{tabular}

\subsection{Ingestion dose of radionuclides through the intake of groundwater}

In order to assess the impacts of these radionuclides on human health due to oral ingestion of drinking water, the annual effective ingestion dose estimation is essential. The WHO (1993) has given a reference ingestion dose level of 
TABLE VIII

Radiological properties of natural uranium (Kaye and Laby, 1993).

Propriétés radiologiques de l'uranium naturel (Kaye et Laby, 1993).

\begin{tabular}{cccc}
\hline Isotopes & Specific activity/mg & Mass fraction & Specific activity/mg of U(nat) \\
\hline${ }^{234} \mathrm{U}$ & $231000 \mathrm{~Bq}$ & 0.00534 & $12.3 \mathrm{~Bq}$ \\
${ }^{235} \mathrm{U}$ & $80 \mathrm{~Bq}$ & 0.72 & $0.6 \mathrm{~Bq}$ \\
${ }^{238} \mathrm{U}$ & $12.4 \mathrm{~Bq}$ & 99.2745 & $12.3 \mathrm{~Bq}$ \\
\hline Total & & & $\mathbf{2 5 . 2} \mathbf{B q}$ \\
\hline
\end{tabular}

$100 \mu \mathrm{Sv} . \mathrm{y}^{-1}$ for individual radionuclides, which is calculated for an adult using ICRP (1996) and WHO guidelines. In order to calculate the ingestion dose of these radionuclides, ingestion dose coefficients of $0.048 \mu \mathrm{Sv}_{\mathrm{Bq}}{ }^{-1}$ for Type $\mathrm{F}$ compounds of natural uranium and $0.28 \mu \mathrm{Sv} . \mathrm{Bq}^{-1}$ for radium (ICRP, 1994; ICRP, 1996) have been considered. For ingestion, ICRP (1996) and IAEA (1989) have recommended dose coefficients, or dose per unit intake, expressed as $\mathrm{Sv} / \mathrm{Bq}$ for all the isotopes of uranium. For this purpose, the model of the gastrointestinal tract is coupled to the systemic model for uranium (ICRP, 1995). The annual effective doses due to ingestion of these waters have been estimated using the average water consumption of $1.48 \mathrm{~m}^{3} \cdot \mathrm{y}^{-1}$ by an Indian adult (Dang et al., 1994) and annual geometric mean concentrations or the median of the radionuclides based on the distribution of the data.

In the Bagjata mining area, for U(nat) based on the Jarque-Bera test, which is a symmetric test for normality, the distribution was found to be lognormal $(h=0$, $p=0.36, j=2.05, c=5.9$ ). The histogram for $\mathrm{U}(\mathrm{nat})$ for the Bagjata mining area also shows the distribution to be lognormal. Thus, the geometric mean was used for the dose calculation. In the case of ${ }^{226} \mathrm{Ra}$, based on the Notch box plot, four data were found to be outliers and since $35 \%$ of the data were below the detection limit, the dose was calculated based on the median. Considering the annual geometric mean concentration of $\mathrm{U}(\mathrm{nat})$ of $81.1 \mathrm{~Bq} \cdot \mathrm{m}^{-3}$ and median concentration of ${ }^{226} \mathrm{Ra}\left(8.85 \mathrm{~Bq} \cdot \mathrm{m}^{-3}\right)$, the ingestion dose of these radionuclides for the Bagjata mining area is $9.43 \mu \mathrm{Sv} . \mathrm{y}^{-1}$, having a contribution of $5.76 \mu \mathrm{Sv} . \mathrm{y}^{-1}$ from uranium and $3.67 \mu \mathrm{Sv}^{-\mathrm{y}^{-1}}$ from radium. The specific activity of $\mathrm{U}$ (nat) is $25.2 \mathrm{~Bq} / \mathrm{mg}$ as explained in Table VIII. Thus, $3.22 \mu \mathrm{gl}^{-1}$ of $\mathrm{U}(\mathrm{nat})$ is equivalent to $81.1 \mathrm{mBq} \cdot \mathrm{l}^{-1}$ or $81.1 \mathrm{~Bq} . \mathrm{m}^{-3}$.

In the case of the Banduhurang mining area, for $\mathrm{U}$ (nat), since more than $45 \%$ of the data were below the detection limit, it was not suitable to ascertain the distribution, and the median value $\left(35.3 \mathrm{~Bq} \cdot \mathrm{m}^{-3}\right)$ was taken for dose calculation. For ${ }^{226} \mathrm{Ra}$, based on the lognormal probability plot, the data can be approximated by lognormal distribution with median $=8.5$ and geomean $=9.1$ (approximately 
the same). So the geometric mean $\left(9.1 \mathrm{~Bq} \cdot \mathrm{m}^{-3}\right)$ was used for the dose calculation. The ingestion dose was found to be $6.28 \mu \mathrm{Sv}^{-1} \mathrm{y}^{-1}$, having a contribution of $2.51 \mu \mathrm{Sv} . \mathrm{y}^{-1}$ from uranium and $3.77 \mu \mathrm{Sv} \mathrm{y}^{-1}$ from radium. It can be inferred from the study that the estimated doses reflect the natural background dose via the route of ingestion, which is much lower than the reference limit prescribed by the WHO (1993).

\section{Conclusions}

The concentration range of $\mathrm{U}(\mathrm{nat})$ in the Banduhurang mining area $\left(<0.5 \mu \mathrm{g} . \mathrm{l}^{-1}\right.$ to $\left.27.5 \mu \mathrm{g} .1^{-1}\right)$ was found to be higher than that in the Bagjata mining area $\left(<0.5 \mu \mathrm{g} .1^{-1}\right.$ to $\left.11.2 \mu \mathrm{g} .1^{-1}\right)$, while in the case of ${ }^{226} \mathrm{Ra}$, the concentrations were lower in the Banduhurang mining area $\left(<3.5\right.$ to $\left.82 \mathrm{mBq} . \mathrm{l}^{-1}\right)$ as compared with the Bagjata mining area $\left(<3.5\right.$ to $\left.206 \mathrm{mBq} \cdot \mathrm{l}^{-1}\right)$. The concentration range of radionuclides in both study areas depicts the natural background concentrations and lies well within the USEPA limits except for the ${ }^{226} \mathrm{Ra}$ concentration (206 mBq. $\mathrm{l}^{-1}$ ) in Bagjata village of the Bagjata mining area. Sporadic mineralization resulted in uneven spatial distribution of the radionuclides. Seasonal variation and distribution of radionuclides also did not show any definite trend. However, an extent of dilution can be observed in the monsoon season. A strong correlation of the radionuclides with $\mathrm{pH}$ was also depicted in the study. The ingestion dose to the public through intake of drinking water was found to be $9.43 \mu \mathrm{Sv} \mathrm{y}^{-1}$ and $6.28 \mu \mathrm{Sv}_{\mathrm{y}} \mathrm{y}^{-1}$ for the Bagjata and Banduhurang mining areas, respectively, which lie well within the reference dose given by the WHO.

Acknowledgement. We are grateful to the Board of Research in Nuclear Sciences, Department of Atomic Energy, Government of India, for providing the necessary funding for the study. We are also thankful to the Health Physics Unit, Environmental Survey Laboratory, Jadugoda, and the Department of Environmental Science and Engineering, Indian School of Mines, Dhanbad, for providing the necessary laboratory facilities and other logistic support for the study.

\section{REFERENCES}

Almeida R.M.R., Lauria D.C., Ferreira A.C., Sracek O. (2004) Groundwater radon, radium and uranium concentrations in Região dos Lagos, Rio de Janeiro State, Brazil, J. Environ. Radioact. 73, 323-334.

Bansal V., Tyagi R.K., Prasad R. (1988) Determination of uranium concentration in drinking water samples by fission track method, J. Radioanal. Nucl. Chem. 125, 439-443.

Benes P. (1990) Radium in (Continental) Surface Water, The Environmental Behavior of Radium. Technical Reports Series No. 310, International Atomic Energy Agency, Vienna, pp. 373-418. 
Bhola K.L., Dar K.K., Ramarao Y.N., Suri Sastry C., Mehta N.R. (1964) A review of Uranium and Thorium deposits in India. In: Proceedings of 3rd International Conference of the peaceful uses of Atomic Energy. Multilingual Edition United Nations, Volume 12, pp. 750-756.

Bou-Rabee F. (1995) Estimating the concentration of uranium in some environmental samples in Kuwait after the 1991 gulf war, Appl. Radiat. Isotopes 46, 217-220.

Brown A., Steenfelt A., Kunzennorf H. (1983) Uranium districts defined by reconnaissance geochemistry in south Greenland, J. Geochem. Explor. 19, 127-145.

Brunke M., Gonser T. (1997) The ecological significance of exchange processes between rivers and ground-water, Freshw. Biol. 37, 1-33.

Burcik I., Mikulaj V. (1991) Separation of Thorium, Uranium and Plutonium by Neutral and Basic Organic Extractants, J. Radioanal. Nucl. Chem. 5, 247-255.

Butler A.H., Kahn B. (1995) Radon-222, Radium-226 and Uranium in Georgia Piedmont well water. In: Proceedings of the 1995 Georgia Water Resources Conference, April 11-12, 1995, Athens.

Correia J.A., Weise S.B., Callahan R.J., Strauss H.W. (1987) The Kinetics of Ingested ${ }^{222}$ Rn in Humans Determined from Measurements with 133X. Cooperative Agreement \# CR 8109427 , U.S. EPA, Health Affects Research Laboratories, Cincinnati, OH.

Cothern C.R., Lappenbusch W.L. (1983) Occurrence of uranium in drinking water in the US, Health Phys. 45, 89-99.

Dang H.S., Jaiswal D.D., Parameswaran M., Krishnamony S. (1994) Physical Anatomical, Physiological and Metabolic Data for Reference Man-A Proposal. BARC/1994/E/043.

DePaul V.T., Szabo Z. (2007) Occurrence of Radium-224, Radium-226 and Radium-228 in Water from the Vincentown and Wenonah-Mount Laurel Aquifers, the Englishtown Aquifer System, and the Hornerstown and Red Bank Sands, Southwestern and South-Central New Jersey. Scientific Investigations Report 2007-5064, Prepared in cooperation with the New Jersey Department of Environmental Protection.

Fentiman A.W., Smith M., Veley R.J. (2004) How do radioactive materials move through the environment to people? Ohio State University Extension. www.ag.ohio-state.edu/rer /rerhtml/rer 25.html

Firestone B.R., Shirley M.C., Baglin Y.S., Frank Chu, Zipkin J. (1996) The 8th Edition of the Table of Isotopes. CD-ROM, JohnWiley \& Sons, Inc.

Gascoyne M. (1989) High Levels of Uranium and Radium in Groundwater at Canada's Underground, Appl. Geochem. 4, 557-591.

Gilkeson R.H., Cartwright K., Cowart J.B., Holtzman R.B. (1983) Hydrogeologic and geochemical studies of selected natural radioisotopes and barium in groundwater in Illinois, Illinois Department of Energy and Natural Resources report 6, 93.

Goode D.J., Wilder R.J. (2006) Ground-Water Contamination near a Uranium Tailings Disposal Site in Colorado, J. Ground Water 25, 545-554.

Hoffmann W., Kranefeld A., Schmitz-Feuerhake I. (1993) Radium-226 contaminated Drinking water: Hypothesis on an Exposure Pathway in a Population with Elevated Childhood Leukemia, Environ. Health Persp. Suppl. 101, 113-115.

Hsi C.D., Langmuir D. (1985) Adsorption of Uranyl onto Ferric Oxyhydroxides: Application of the Surface Complexation Site-Binding Model, Geochim. Cosmochim. Acta 49, 1931-1941.

IAEA (1989) International Atomic Energy Agency. Measurement of radionuclides in food and the environment: A guidebook. IAEA Technical Reports Series, 295. IAEA, Vienna.

ICRP Publication 68 (1994) International Commission on Radiological Protection. Dose Coefficients for Intakes of Radionuclides by Workers, Ann. ICRP 24(4).

ICRP Publication 69 (1995) International Commission on Radiological Protection. Age-dependent Doses to Members of the Public from Intake of Radionuclides: Part 3 Ingestion Dose Coefficients, Ann. ICRP 25(1). 
ICRP Publication 72 (1996) International Commission on Radiological Protection. Age dependent doses to the members of the public from intake of radionuclides: Part 5, Ann. ICRP 25(2).

Iyengar M.A.R. (1990) The Natural Distribution of Radium, The Environmental Behavior of Radium. Technical Reports Series No. 310, IAEA 1, 9-128.

Kaye G.W.C., Laby T.H. (1993) Tables of physical and chemical constants. Longman Group Ltd, 15 th edition, Essex, UK.

Kolthoff I.M., Elving P.J. (1962) Treatise on Analytical Chemistry, part II, Vol. 9.

Kumru M.N. (1995) Distribution of Radionuclides in sediments and soils along the Buyuk Menderes River, Proc. Pakistan Acad. Sci. 32, 51-56.

Labidi S., Dochraoui M., Mahjoubi H., Lemaitre N., Ben Salah R., Mtimet S. (2002) Natural Radioactive Nuclides in Some Tunisian Thermo-Mineral Springs, J. Environ. Rad. 62, 87-96.

Lauria D.C., Almeida, R.M.R., Sracek O. (2004) Behavior of radium, thorium and uranium in groundwater near the Buena Lagoon in the Coastal Zone of the State of Rio de Janeiro, Brazil, Environmental Geology 47, 11-19.

Lydie R.M., Nemba, R.M. (2008) Quantitative Determination of ${ }^{226}$ Ra and ${ }^{228}$ Ra in Reservoir and Tap Water in Yaounde Area, Cameroon, Global Journal of Environmental Research 2, 110-113.

Mackenzie J.M.W. (1997) Uranium Solvent Extraction Using Tertiary Amines. In: Uranium Ore Yellow Cake Seminar. February 1997 Melbourne, Australia.

Mahesh H.M., Avadhani D.N., Somashekarappa H.M., Karunakara N., Narayana Y., Siddappa K. (2002) Uranium and Radium concentration in ground water in the environment of coastal Karnataka and Kaiga. In: Proceedings National Symposium in Environment-XI, pp. 123-127.

Malcome-Lawes D.J. (1979) Introduction to Radiochemistry. Unwin Brothers Ltd.

Marovic G., Sencar J., Franic Z., Lokobaner N. (1996) Radium-226 in Thermal and mineral Springs of Croatia and Associated Health Risk, J. Environ. Rad. 33, 309-317.

Nour Khalifa A. (2004) Natural Radioactivity of Ground and drinking water in some areas of Upper Egypt, Turkish. J. Eng. Env. Sci. 28, 345-354.

Paschoa A.S., Baptista G.B., Montenegro E.C., Miranda A.C., Sigaud G.M. (1979) Radium-226 Concentrations in the Hydrographic Basins near Uranium Mining and Milling in Brazil. In: Proc. of the Mid Year Topical Symposium, Low Level Radioactive Waste Management, Williamsburg, VA, pp. 337-343.

Pulhani V.A., Dafauti S., Hegde A.G. (2007) Leaching of uranium, radium and thorium from vertisol soil by ground water, J. Radioanal. Nucl. Chem. 274, 341-343.

Raghavayya M., Iyengar M.A.R., Markose P.M. (1980) Estimation of Radium-226 by Emanometry, Bull. IARP 3(4).

Rani A., Singh S. (2006) Analysis of uranium in drinking water samples using laser induced fluorimetry, Health Phys. 91, 101-107.

Rout K.C., Mishra P.K., Chakravorty V., Dash K.C. (1994) Liquid-liquid extraction of uranium(VI) by Cyanex 301/Alamine 308 and their mixtures with TBP/DDSO, J. Radioanal. Nucl. Chem. 181, 3-10.

Salonen L. (1988) Natural Radionuclides in Groundwater in Finland, Radiat. Prot. Dosim. 24, 163-166.

Santschi P.H., Hoehn E., Lueck A., Farrenkothen K. (1987) Tritium as a tracer for the movement of surface water and groundwater in the Glatt valley, Switzerland, Environ. Sci. Technol. 21, 909916.

Schwarzenbach R.P., Giger W., Hoehn E., Schneider, J.K. (1983) Behavior of organic compounds during infiltration of river water to groundwater, Environ. Sci. Technol. 17, 472-479.

Shiraishi K., Igarashi Y., Takaku Y., Masuda K., Yoshimizu K., Nishimura Y., Hongo S., Yamaguchi H. (1992). Daily intakes ${ }^{232}$ Th and ${ }^{238} \mathrm{U}$ in Japanese male, Health Phys. 63, 187-191. 
Sidhu K.S., Breithart M.S. (1998) Naturally Occurring Radium-226and Radium-228 in Water Supplies of Michigan, Bull. Environ. Contam. Toxicol. 61, 722-729.

Silva P.S.C., Damatto S.R., Mazzilli B.P. (2008) Sequential Determination of U and Th Decay Series in Santana Cave, Southwest Brazil. In: The Natural Radiation Environment: 8th International Symposium (NRE VIII). AIP Conference Proceedings, 1034, pp. 256-259.

Smith B., Powell A.E., Milodowski A.E., Hards V.L., Hutchins M.G., Amro A., Gedeon R., Kilani S., Scrivens S.M., Galt V. (2000) Identification, investigation and remediation of ground water containing elevated levels of uranium-series radionuclides: A case study from the Eastern Mediterranean. In: Proc. of the 3rd Int. Conf. on the geology of the eastern Mediterranean, Nicosia, Cyprus. Geneva: WHO/SDE/PH/01.1.

Sophocleous M. (2002) Interactions between groundwater and surface water: the state of the science, Hydrogeology Journal 10, 52-67.

Szabo Z., Zapecza O.S. (1991) Geologic and Geochemical Factors Controlling Uranium, Radium-226, and Radon-222 in Ground Water, Newark Basin, New Jersey. In: Field Studies of Radon in Rocks, Soils, and Water, (Gundersen L.C.S., Wanty R.B., eds.) U.S. Geological Survey Bulletin. pp. 243-266.

Tripathi R.M., Sahoo S.K., Jha V.N., Khan A.H., Puranik V.D. (2007) Assessment of Environmental radioactivity at uranium mining, processing and tailings management facility at Jadugoda, India. In: Proc. of Int. Conf. on Environmental Radioactivity during April 23- 28, 2007 at IAEA, Vienna.

Ulbak K., Klinder O. (1984) Radium and Radon in Danish Drinking Water, Radiat. Prot. Dosim. 7, 87-89.

UNSCEAR (2000) United Nations Sources and Effects of Ionising Radiation, Report to the General Assembly with Scientific Annexes, United Nations, New York. Vol. 1, pp. 126-127.

US Geological Survey and New Jersey Dept of Env. Protection (2004) Occurrence of Radium-224, Radium-226 and Radium-228 in water of the unconfined Kirkwood-Cohansey Aquifer system, Southern New Jersey. Scientific Investigations.

USEPA (1976) Determination of Radium Removal Efficiencies in Water Treatment Process. Technical Note. ORP/TAD-76-5, Illinois, EPA, Springfield. http://www.epa.gov.

Vesterbacka P., Turtiainen T., Heinävaara S., Arvela, H. (2006) Activity concentrations of ${ }^{226}$ Ra and ${ }^{228} \mathrm{Ra}$ in drilled well water in Finland, Radiat. Prot. Dosim. 121, 406-412.

Wanty R.B., Johnson S.L., Briggs P.H. (1991) Radon-222 and its parent radionuclides in groundwater from two study areas in New Jersey and Maryland, U.S.A., Appl. Geochem. 6, 305-318.

Weihai Z., Takao I., Xiaotang Y. (2001) Occurrence of Rn-222, Ra-226, Ra-228 and U in Groundwater in Fujian Province, China, J. Environm. Radioact. 53, 111-120.

Whittemore D.O., McElwee C.D., Tsu M.S. (2000) Arkansas River salinity and contamination of the High Plains aquifer (W.O. Deason, T.K. Gates, D.D. Zimbelman, S.S. Anderson, eds) Challenges facing irrigation and drainage in the new millennium. In: Proc 2000 USCID Intl Conf, Fort Collins, CO. 1, 225-246.

WHO (1978) Radiological Examination of Drinking Water, World Health Organization, Copenhagen.

WHO (1993) Guidelines for drinking water quality. World Health Organization, Geneva.

WHO (2004) Guidelines for Drinking-water Quality: Recommendations by World Health Organization, Edition: 3, Published by World Health Organization.

Wrenn M.E., Durbin P.W., Howard B., Lipsztein J., Rundo J., Still E.T., Willis D.I. (1985) Metabolism of Ingested U and Ra, Health Phys. 48, 601-633. 